\title{
1 Taphonomic evidence supports an aquatic 2 lifestyle for Spinosaurus
}

4 Thomas Beevor ${ }^{a}$, Aaron Quigley ${ }^{a}$, Roy E. Smith ${ }^{a}$, Robert S.H. Smyth ${ }^{a}$, Nizar

5 Ibrahim $^{a, b}$, Samir Zouhric, David M. Martilla

6

aSchool of the Environment, Geography and Geoscience, University of Portsmouth, Burnaby Road, Portsmouth PO1 3QA, UK.

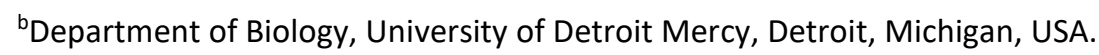

'Laboratoire de Biodiversité et Santé, Faculté des Sciences Aïn Chock, Université Hassan II, Casablanca, Morocco.

ABSTRACT

A new locality near Tarda on the northern margin of the Tafilalt, south eastern Morocco exposes extensive sequences of the Ifezouane and Aoufous formations of the fluvial Kem Kem Group (Cretaceous, ?Albian-Cenomanian) on the south western flank of Ikfh n'Oufza escarpment of the Hamada du Meski. The stratigraphic sequence here differs significantly from better known exposures of the Kem Kem Group in the southern Tafilalt, and includes a heterolithic sequence of alternating grey mudstones and fine sandstones and a thin $(\sim 1.5 \mathrm{~m})$ marine limestone. The locality is noteworthy for three vertebrate-bearing horizons within the upper part of the Ifezouane Formation. The upper two (Sites 1 and 2 in ascending order) are dominated by dental remains of the sawfish Onchopristis and the aquatic theropod dinosaur Spinosaurus. Significantly, the remains of terrestrial dinosaurs constitute less than $1 \%$ of the total dental assemblage at Site 1 and $5.6 \%$ at Site 2. At Site 2 teeth of Spinosaurus outnumber the rostral "teeth" of Onchopristis. The remarkably high abundance of spinosaur teeth compared to remains of terrestrial dinosaurs, and even some aquatic animals strongly supports Spinosaurus being an aquatic animal spending much of its life in water where its teeth were shed and preserved.

Key words: Cretaceous; Dinosauria; Spinosaurus; Taphonomy; Palaeoecology; Morocco 


\section{Introduction}

The enigmatic theropod dinosaur Spinosaurus aegyptiacus Stromer, 1915 has been interpreted as a piscivorous and semi-aquatic animal (Stromer, 1936, Taquet, 1984; Ibrahim et al., 2014; Arden et al., 2019), and more recently shown to have possessed a highly modified tail suited for propelling the animal through water (Ibrahim et al., 2020a). The hypothesis that this spectacular dinosaur was semi-aquatic - or even perhaps fully aquatic - has met with some opposition (e.g. Henderson, 2018; Hone and Holtz, 2019), not least because it challenges decade-old ideas on dinosaur ecology and evolution. Evidence for an aquatic lifestyle hinges mainly on skeletal data, which provides compelling evidence, including a rearward position of the external nares, flattened pedal unguals and considerable divergence of pedal digits, a series of elongate neural spines on the caudal vertebrae giving the tail a fin-like morphology, a reduced pelvic girdle and hindlimb, with a disproportionately short femur and osteoclerosis/pachyostosis of the skeleton (Ibrahim et al., 2020a), as well as circumstantial evidence for specialized sensory structures to detect prey in water (Ibrahim et al., 2014). Possession of a narrow, somewhat crocodile-like overall skull morphology and a dentition of simple conical teeth, often with pronounced apicobasal ridges, has also been interpreted as indicating a piscivorous diet (Stromer 1936, Taquet 1984, Ibrahim et al., 2014; McCurry et al., 2019). Comparisons with more distantly related forms - large piscivorous fish - have also been used to support piscivory in Spinosaurus (Vullo et al., 2016). Additional evidence from phylogenetic analysis suggest a very close relationship to the European Baryonyx walkeri, a spinosaurid in which possibly acid-etched lepidotid fish scales were discovered in the ribcage, providing potential evidence for a degree of piscivory in these animals (Charig and Milner, 1986, 1997). Isotopic evidence was also used to suggest an aquatic lifestyle for Spinosaurus by Amiot et al. (2010), although the data was somewhat inconclusive. Taken together, these diverse and independent lines of evidence all point toward a largely piscivorous - and aquatic - lifestyle. Here we present evidence from a taphonomic analysis of a new locality of the Kem Kem Group strata of south east Morocco that further strengthens a predominantly aquatic lifestyle for Spinosaurus.

Most museum specimens of Spinosaurus from Morocco have been obtained from commercial sources, and generally lack precise locality or horizon data (Ibrahim et al., 2020a). Our field studies over the last 15 years in the Tafilalt region and Hamada du Kem Kem of south east Morocco reveal that a majority of this material comes from the top of the Ifezouane Formation of the Kem Kem Group. Many isolated teeth, occasional jaw fragments and, more rarely, postcranial bones are dug 
by artisan miners from three or four event horizons characterised by mud-flake conglomerates with chaotic bedding, and sharp basal contacts. They are rarely more than $1 \mathrm{~m}$ thick, and often just a few centimetres, but may be extensive and traceable over several kilometres. The discovery of an associated skeleton by Ibrahim et al., (2020a) is an exception, as this specimen is one of only three associated dinosaurs reported from the Kem Kem Group (Ibrahim et al., 2020a), and it occurred at a slightly higher level in the sequence.

\section{Locality and geological context}

\subsection{Locality}

The data reported here was obtained from natural exposures at the foot of the Ikfh n'Oufza escarpment, the western extension of the Hamada du Meski between Goulmima and Er Rachidia on the northern margin of the Tafilalt Basin in south east Morocco. This locality lies within Errachidia Province near the village of Tarda on the eastern side of the Oued Tarda (Fig. 1). Exposure is extensive, patchily continuous for $\sim 2.4 \mathrm{~km}$, and has been quarried and mined in several places specifically for the extraction of fossils.

The Kem Kem Group strata represent an extensive fluvial system that can be traced in Morocco for at least $200 \mathrm{~km}$ from Zguilma in the south west to Aoufous and beyond to the Anoual Basin and the frontier with Algeria. In Algeria, coeval strata yield remarkably similar vertebrate assemblages both in terms of faunal diversity and taphonomy (Benyoucef et al., 2015; Ibrahim et al., 2020a,b). Vertebrate fossils occur at event horizons (likely flash-flood deposits and viscous sediment flows, as channel lags and as exceptionally rare isolated associated skeletons (Ibrahim et al., 2014, 2020a,b). The vertebrate assemblage is diverse (for a full faunal list see Cavin et al., 2010; Ibrahim et al., $2020 b$ ) and includes a wide variety of cartilaginous and bony fishes, archosaurs (dinosaurs, pterosaurs and crocodiles), turtles and snakes and lizards. There are anomalies such as a near absence of ornithischian dinosaurs and a lack of mammals, which have yet to be reported from the Kem Kem Group (Ibrahim et al., 2020a,b).

\subsection{Geological context}

The strata from which the fossils discussed here came comprise a suite of largely clastic red mudstones, fine sandstones and thin conglomerates (pebble and mud-flake) of the Kem Kem Group. They rest unconformably on folded Palaeozoic basement rocks and are overlain by marine 
Carbonates of the Akrabou Formation that is well dated as Middle Cenomanian to Turonian (Ettachfini and Andreu, 2004; Kennedy et al., 2008). In the north of the Tafilalt the Kem Kem Group has been divided into two formations, a lower Ifezouane Formation dominated by fine sands with event horizons yielding fossils vertebrates, and an upper Aoufous Formation that is comprised largely of variegated mudstones with thin-bedded sandstones. This latter formation generally lacks fossil vertebrates, except near Aoufous (Oum Tkout) where a thin horizon of laminated mudstones yields fully articulated skeletons of fish and amphibians in a lacustrine Konservat Lagerstätte (Dutheil, 1999; Cavin et al., 2010; Ibrahim et al., 2020b).

At Tarda the base of the Kem Kem Group is not seen and the sequence commences with a series of greyish mudstones with thin beds of gypsum and thin ( $20-50 \mathrm{~mm}$ thick) siltstones with halite pseudomorphs. These pass upwards into a sequence of massively bedded and cross bedded fine sandstones with occasional clay partings a few tens of centimetres thick. The sequence continues to be dominated by fine sandstones upwards until it passes into a series of variegated mudstones capped by a yellow weathering well-bedded limestone with Thalassinoides. This represents a brief marine intercalation but has only yielded a shelly fauna of very small bivalves resembling modiolids and a heterodont near Zrigat, a few kilometres to the east. This limestone is prominent in the landscape for its colour and also for producing the cap to a smaller plateau sitting lower than the dominating Hamada de Meski that forms the northern margin of the Tafilalt Basin. Above the thin yellowish limestone is a series of variegated (grey, blue-grey, orange, ochreous and red) sandstones that form the upper part of the Ifezouane Formation. These sandstones pass up into variegated mudstones with thin sandstones of the Aoufous Formation and are in turn capped by limestones of the Akrabou Formation that form the top of the Hamada du Meski. A preliminary sedimentary log for the exposure is provided in figure 2 .

The Akrabou Formation limestones are dated as mid Cenomanian to Turonian on the basis of a diverse ammonite assemblage (Kennedy et al., 2008), but the age of the Kem Kem Group is not securely determined. Several authors, using the fossil vertebrates, have suggested a Lower Cenomanian age for the Kem Kem Group by comparing it with the Bahariya Formation of the Egyptian Western Desert (Sereno et al., 1996; Ibrahim et al., 2020b), but it may well be somewhat older, as there is a considerable thickness of strata and a number of disconformities between the vertebrate-bearing Ifezouane Formation and the base of the Akrabou Formation.

\subsection{Taphonomic context}


The two vertebrate-bearing horizons examined (Sites 1 and 2 [red and yellow stars respectively in Fig. 2]) differ sedimentologically and taphonomically. At Site 1 the vertebrate remains occur at the base of a brown weathering fine-grained lenticular sandstone channel that can be traced laterally for only a few tens of metres. The vertebrate remains often occur as broken fragments, are randomly orientated and brittle. Bone and dentine are white while enamel is pale yellow to orange. In places the sandstone is extremely well cemented by iron oxides, where it is a darker brown or buff colour. By contrast at Site 2 the vertebrate remains are restricted to a thin but laterally more continuous layer representing an event horizon more typical of other vertebrate-bearing horizons in the Ifezouane Formation, such as Ouzina and Begaa (e.g. Ibrahim et al., 2016; Martill et al., 2018 respectively). At these localities fossil vertebrates occur in thin debris sheet flows that in places are mud-flake conglomerates, with matrix-supported clasts and chaotic bedding.

\section{Methods, aims and objectives}

During reconnaissance field work in the vicinity of Tarda in the northern Tafilalt of south east Morocco we discovered a bone bed at the base of a sandstone channel that had been exploited by local fossil diggers. Many large blocks of indurated sandstone lay around the abandoned diggings and all were rich in the teeth of Spinosaurus, rostral 'teeth' of the sawfish Onchopristis and circular vertebrae that we also attribute to Onchopristis (see Ibrahim et al., 2020b). Weathered spoil dumps from the small artisan mines were also collected and analysed for abundance data.

Just 1.5 kilometres distant we located an active mine site and met with a number of artisan fossil miners. One of us (DMM) purchased all of the fossils that a digger had obtained and put into a large sack (total number of elements $=1261$ ). All of this material had been obtained from one stratigraphic level in the upper part of the Ifezouane Formation and is indicated as Site 2 on Fig. 1 (stratigraphic nomenclature follows Ettachfini and Andreu, 2004).

Specimens cited in this work are accessioned in the following institutions: BSP, Staatliche

151 Naturwissenschaftliche Sammlungen Bayerns - Bayerische Staatssammlung für Paläontologie und

152 Geologie, Munich, Germany; DINO, Dinosaur National Monument, Utah, USA; FSAC, Département de 153 Géologie, Faculté des Sciences Aïn Chock, Université Hassan II, Casablanca, Morocco; MIWG, Dinosaur Isle Museum, Sandown, Isle of Wight, UK; MN/UFRJ, Museu Nacional /Universidade Federal, Rio de Janeiro, RJ, Brazil; MNHN, Museum National d'histoire Naturelle, Paris, France; MSNM, Museo di Storia Naturale di Milano, Italy; MUCP, Museo de la Universidad Nacional del 
Comahue, El Chocon Collection, Argentina: MUO, Museum of the University of Oklahoma, USA; NHMUK, Natural History Museum, London, UK; SMNS, Staatliches Museum für Naturkunde Stuttgart, Stuttgart, Germany; USP, University of Sao Paulo, SP, Brazil.

\section{Results.}

\subsection{Site 1}

Collecting from Site 1 at a horizon below the Yellow Limestone Member (See Figs 2, 3) in the lower Ifezouane Formation yielded a total of 926 vertebrate fossils, of which 317 (34.2\%) were teeth (including Onchopristis rostral denticles) (Table 1A). Microvertebrate remains were not collected. We focussed our analysis on dental remains as all of these could be confidently assigned to a taxon at least at ordinal level or better (Table 1B, even when fragmentary). Only 6 distinct tooth morphotypes were present in the assemblage (Table 1B). Of these, the teeth of Spinosaurus (Figs. 4, 5) comprised almost $48 \%$ of the total dental remains and $16.4 \%$ of the total vertebrate fossils from this site.

Although much of the dental material is fragmentary (see Figs 4,5 ) it can easily be identified into broad taxonomic groups and sometimes genera. For Spinosaurus teeth we used criteria described and figured by Richter et al., (2013) and Hendrickx et al., (2019).

Thus, remarkably, Spinosaurus teeth were only slightly less numerous than the most common elements of the dental assemblage, the rostral denticles of the sawfish Onchopristis numidus (Table $1 \mathrm{~A})$. The only other dinosaur present in the dental assemblage at this locality is the allosauroid Carcharodontosaurus sp., represented by a single broken tooth. The results show that Spinosaurus and Onchopristis are the most abundant fossils at this locality by a considerable margin (Fig. 6A, B).

\subsection{Site 2}

Site two yielded a more diverse assemblage than Site 1, where a total of 1261 vertebrate fossils were obtained. They were purchased from an artisan miner at his mine, and all originate from a single event horizon in the upper Ifezouane Formation occurring above the Yellow Limestone Member (Figs. 2, 3). We acknowledge that it is likely that this assemblage of fossils may have had some larger bones and more valuable larger teeth removed. It is likely that this would have been only a small number (pers. obs.). Of the material, 928 specimens $(73.6 \%)$ represent dental remains (Table 2A, B). The diversity of teeth at this site is significantly greater than at site 1 , with at least 12 morphotypes represented. The most abundant tooth morphotype at Site 2 are the conical, faceted 
teeth of Spinosaurus sp., (407 teeth) which comprised $43.9 \%$ of the dental sample and $32.3 \%$ of the total vertebrate material at this site. Although many of the Spinosaurus teeth are too fragmentary to be confidently placed within distinct morphotypes (sensu Richter et al., 2013), we were able to allocate 225 out of a total of 407 teeth (Fig. 7). The abundances of the three morphotypes approximate those of Richter et al (2013). The second most abundant dental remains are attributed to Onchopristis with a total of 375 (40.4\%) rostral denticles (Fig. 6C, D).

\subsection{Comparisons between sites 1 and 2}

Although there are considerable similarities between the two vertebrate assemblages, there are also some significant differences that likely reflect subtle differences in habitat preference between taxa and taphonomic filters such as size and density sorting. Dinosaur diversity is considerably greater at Site 2 than Site 1, but the numbers of non-spinosaurid dinosaur teeth are low, and combined they constitute no more than $4.2 \%$ of the total assemblage and $5.6 \%$ of the dental assemblage. Where taxa are known from a single example we do not regard this as significant, and of those taxa that are common to both sites (Carcharodontosauridae; Spinosaurinae; Onchopristis numidus), only Onchopristis and Spinosaurus are found in any abundance. An intriguing discrepancy between the two sites is the lack of vertebrae attributable to Onchopristis at Site 2. These easily identified elements constitute $41 \%$ of the vertebrate remains at Site 1 , and are reasonably common at many sites in the eastern and southern outcrops of the Kem Kem Goup (Ibrahim et al., 2020b). This discrepancy is unexpected and not easy to explain. We cannot rule out that the fossil digger at Site 2 considered them to have no commercial value and left them in the mine, but this has not been our experience of other dig sites. An element of density sorting may be at play with the relatively light vertebrae having been winnowed away.

\section{Discussion}

213 The relative abundances of dental remains for the two distinct stratigraphic intervals collected at

214 Tarda reveals that teeth of Spinosaurus occur in high abundance at both levels, but are exceptionally 215 abundant at Site 1 where they constitute $48 \%$ of the dental remains. We know of no other dinosaur216 bearing bone bed where such an abundance of dinosaur teeth occurs. The enhanced abundance of Spinosaurus teeth relative to other dinosaurs is likely a reflection of their aquatic lifestyle. An animal living much of its life in water is much more likely to contribute teeth to the river deposit than those dinosaurs that perhaps only visit the river for drinking and more casual feeding on its banks, or the 
occasional carcass of a terrestrial dinosaur decomposing in the river. Similarly, the high abundance of rostral denticles of Onchopristis is hardly surprising, given that sawfish are fully aquatic animals, and that elasmobranchs are noteworthy for their efficiency in growing and replacing teeth (Slaughter and Springer, 1968). What is perhaps surprising is the rarity of other fish teeth, especially the more robust teeth of holosteans such as Lepidotes $\mathrm{sp}$. and pycnodonts, although the latter are rare in the Kem Kem Group (Cooper and Martill, 2020), the former occur frequently and reached a large size.

Our results largely agree with those of Läng et al., (2013) who sampled the Ifezouane Formation in the southern Tafilalt and Benyoucef et al., (2015) who sampled the Algerian Kem Kem Group in the Guir Basin, although we note some differences. In the southern Tafilalt, amalgamated results for six horizons at three localities suggest that theropod remains (including Spinosaurus) constitute only $\sim 6 \%$ of the assemblage. However, at the majority of their localities and horizons, the teeth of Spinosaurus outnumbered those of all other dinosaurs combined. In Algeria, Benyoucef et al. (2015) found that dinosaurs formed a much smaller component of all taxa reported from Béchar. However, in considering just the dinosaur remains, those identified as Spinosaurus represented $94 \%$ of the theropod dental assemblage. At Site 1 in Tarda Spinosaurus constitutes 99\% of the theropod dental assemblage, and at Site 2 this value is $89 \%$. Clearly Spinosaurus teeth are the most abundant dinosaur dental remains in the Kem Kem Group, over all of its outcrop. There are considerable differences in the relative abundances of non-dinosaurian remains between these localities, but discussion of this is beyond the scope of this analysis. We do add, however, that the similarity of distribution of vertebrate remains in the material collected from Site 1 compared to that collected by the miners at Site 2 is noteworthy, especially with regard to the distribution of remains of aquatic forms. Despite the difference in collecting methods (fossil miners vs research collecting), this strongly supports our observation that Onchopristis and Spinosaurus represent the largest components of the assemblages at both sites. It would seem odd surely, if the fossil collectors at Site 1 deliberately left behind the remains of Onchopristis and Spinosaurus (for researchers to find) while those at Site 2 collected only these taxa.

\subsection{Relative abundances} The abundance and availability of teeth for inclusion in a bone bed is controlled by both biological and taphonomic factors. Biological factors include tooth replacement, number of teeth per taxon, 
longevity and number of individuals in population of the catchment area. In palaeontology many of these are unknows, including even the total number of teeth in the jaws. For Spinosaurus the tooth count is estimated to be $\sim 68-72$ (see Table 3 ).

Theropod teeth were replaced on a regular basis, as they are in modern crocodilians (Currie, et al., 1990), where tooth replacement is irregular and affected by age and size of the individual crocodile, with irregularity of replacement increasing with age (Edmund, 1962). The functional life of each tooth differs from approximately nine months in anterior teeth, to sixteen in posterior teeth (Edmund, 1962). Teeth are replaced in waves from front to back in juveniles, and reversed in older individuals (Edmund, 1962). It has been suggested that theropods had a very similar tooth functional life to crocodilians of between nine and sixteen months per tooth. The presence of theropod teeth among some herbivorous dinosaur remains indicates that theropods may have lost one or more teeth in some feeding sessions, suggesting tooth replacement was rather constant and relatively rapid (Currie, et al., 1990). Erickson et al., (1996) notes a duration for replacement teeth of up to 777 days for an adult Tyrannosaurus, while D'Emic et al., (2019) found as little as 56 days for Majungasaurus and 104 days for Allosaurus, both of which may be considered as tentative proxies for Kem Kem abelisaurids and Carcharodontosaurus respectively. We speculate that Spinosaurus may have had a tooth replacement duration within the 56 to 777 day range. We also note that the abelisaur with the highest tooth replacement rate has a low abundance in the Kem Kem Group (Tables 1, 2), suggesting perhaps that they were not an important part of this palaeobiotope.

The number of teeth in the jaw at any one time varies considerably between taxa in the Dinosauria, but for Spinosauridae it is probably between 68 and 72 (Spinosaurus) and 94 (Baryonyx) (Table 3). The total tooth count for Carcharodontosaurus is not known, but related allosauroids have total counts of between 60 and 80 (Table 3), which suggests that Spinosaurus is not particularly different from other theropods roaming the Kem Kem biotopes. Likewise, there is little reason to suspect that tooth shedding rates would be very different between Spinosaurus and Carcharodontosaurus (although of course they may have been), or the numbers of teeth during the course of their lifetime. Likely the greater abundance of Spinosaurus teeth compared to Carcharodontosaurus and the abelisaurs in the Kem Kem is that spinosaurids were present in greater numbers in this largely fluvial environment dominated by aquatic organisms (Ibrahim et al. 2020a,b and papers therein), and inhabited the sedimentary environment in which their teeth are preserved.

Of course, it is possible that the abundance of Spinosaurus remains in a fluvial deposit are the result of a wading heron-like ecology, snatching prey from shallow water as has been suggested by some authors (Taquet, 1984; Hone and Holtz, 2017, 2019; Henderson, 2018). An elongated skull and neck 
relative to those of other large theropods is consistent with this interpretation (although these features are also consistent with diverse swimming birds). However, other aspects of the morphology of Spinosaurus are inconsistent with wading mode of life. Wading has developed independently several times in extant theropods, always converging on similar hindlimb morphologies. Wading birds are characterised by having hindlimbs that are longer, relative to body size, than those of other birds, with the tibiotarsus and tarsometatarsus disproportionately extended (Zeffer et al., 2003). Such a morphology increases foraging area (Baker, 1979) reduces drag, increasing efficiency while moving through water (Zeffer et al., 2003). These adaptations presumably also have the added benefit of reducing water disturbance that may alert potential aquatic prey to the presence of a predator.

In contrast, the hindlimbs of Spinosaurus are greatly shortened relative to body size, with disproportionate reduction of the femur (Ibrahim et al., 2014). Not only are these hindlimb proportions inconsistent with those of a wading animal, they suggest that Spinosaurus is more poorly adapted to a wading mode of life than any other non-avian theropod (perhaps with the exception of those paravians with elaborately feathered hindlimbs). Overall reduction in hindlimb length, that disproportionately affects the femur is consistent with only one form of avian locomotion: active swimming (Zeffer et al., 2003).

Taken in conjunction, both morphological analysis and now taphonomic data strongly support a predominantly aquatic mode of life for Spinosaurus.

\section{Conclusions}

The teeth of Spinosaurus occur in high abundance in two bone-bearing horizons at the Tarda locality of the Kem Kem Group. The abundance of Spinosaurus at both levels in comparison to terrestrial dinosaurs such as the gigantic theropod Carcharadontosaurus, the somewhat smaller abelisaurs and sauropods is substantial. In the lower horizon, a channel-lag bone bed, teeth of Spinosaurus outnumber terrestrial dinosaur teeth by a factor of $\sim 150$ to 1 . In addition, at this horizon the teeth of Spinosaurus are more abundant even than many aquatic and semi-aquatic animals such as bony fishes and crocodyliforms. At a slightly higher horizon in the same stratigraphic unit Spinosaurus teeth outnumber those of all other dental remains, and outnumber other dinosaur teeth by a factor of $\sim 8$ to 1 . While all of the fossils collected from these horizons should be considered semiautochthonous, it would seem that for such an abundance of teeth of Spinosaurus to occur, it is highly likely that this animal was living mostly within the river rather than along its banks. This conclusion is consistent with interpretations of Spinosaurus' palaeoecology based on anatomical evidence (Ibrahim, et al., 2014, 2020a). Furthermore, the channel-lag bone bed at Site 1 is the first 
reported occurrence of a bone-bed dominated by dinosaur teeth, and represents a unique thanatocoenosis.

\section{Acknowledgements}

Data for this study was collected in Morocco in October and November 2019 and benefited from the 2018 and 2019 University of Portsmouth expeditions including Dr Michael Oates, Mr Simon Penn and Mr Laurence Breeze. We thank Mr Geoff Long for the preparation of thin sections of a very high standard (as always). We thank Lionel Cavin and an anonymous referee for their helpful comments that undoubtedly improved our manuscript.

\section{References}

Amiot, R., Buffetaut, E., Lecuyer, C., Wang, X., Boudad, L., Ding, Z., Fourel, F., Hutt, S., Martineau, F., Medeiros, M.A., Mo, J., 2010. Oxygen isotope evidence for semiaquatic habits among spinosaurid theropods. Geology 38, 139-142.

Arden, T.M., Klein, C.G., Zouhri, S., Longrich, N.R., 2019. Aquatic adaptation in the skull of carnivorous dinosaurs (Theropoda: Spinosauridae) and the evolution of aquatic habits in spinosaurids. Cretaceous Research 93, 275-284.

Baker, M.C., 1979. Morphological correlates of habitat selection in a community of shorebirds (Charadriiformes). Oikos, 121-126.

Benyoucef, M., Läng, E., Cavin, L., Mebarki, K., Adaci, M., Bensalah, M., 2015. Overabundance of piscivorous dinosaurs (Theropoda: Spinosauridae) in the mid-Cretaceous of North Africa: The Algerian dilemma. Cretaceous Research 55, 44-55.

Brusatte, S.L., Benson, R.B.J., Hutt, S., 2008. The osteology of Neovenator salerii (Dinosauria: Theropoda) from the Wealden Group (Barremian) of the Isle of Wight. Monograph of the Palaeontographical Society 162, 1-75. 
Brusatte, S.L., Sereno, P.C. 2007. A new species of Carcharodontosaurus (Dinosauria: Theropoda) from the Cenomanian of Niger and a revision of the genus, Journal of Vertebrate Paleontology 27, 902-916. https://doi.org/10.1671/02724634(2007)27[902:ANSOCD]2.0.CO;2

Cavin, L., Tong H., Boudad, L., Meister, C., Piuz, A., Tabouelle, J., Aarab, M., Amiot, R., Buffetaut, E., Dyke, G., Hua, S., Le Loeuff, J., 2010. Vertebrate assemblages from the early Late Cretaceous of southeastern Morocco: An overview. Journal of African Earth Sciences 57, 391-412. https://doi.org/10.1016/j.jafrearsci.2009.12.007

Charig, A.J., Milner, A.C., 1986. Baryonyx, a remarkable new theropod dinosaur. Nature 324(6095), 359-361.

Charig, A.J., Milner, A.C., 1997. Baryonyx walkeri, a fish-eating dinosaur from the Wealden of Surrey. Bulletin of the Natural History Museum: Geology Series 53(1), 11-70.

Chure, D.J., Loewen, M.A., 2020. Cranial anatomy of Allosaurus jimmadseni, a new species from the lower part of the Morrison Formation (Upper Jurassic) of Western North America. PeerJ 8, p.e7803.

Cooper, S.L., Martill, D.M., 2020. A diverse assemblage of pycnodont fishes (Actinopterygii, Pycnodontomorpha) from the mid-Cretaceous, continental Kem Kem Group of South-East Morocco. Cretaceous Research, p.104456. https://doi.org/10.1016/i.cretres.2020.104456

Coria, R.A. and Salgado, L., 1995. A new giant carnivorous dinosaur from the Cretaceous of Patagonia. Nature 377(6546), 224-226.

Currie, P., Rigby, J., Sloan, R., 1990. Theropod teeth from the Judith River Formation of southern Alberta, Canada. In: Carpenter, K., Currie, P.J. (eds), Dinosaur systematics: approaches and perspectives. Cambridge University Press, 107-125.

Dal Sasso, C., Maganuco, S., Buffetaut, E., Mendez, M.A., 2005. New information on the skull of the enigmatic theropod Spinosaurus, with remarks on its size and affinities. Journal of Vertebrate Paleontology 25(4), 888-896.

D’Emic, M.D., O'Connor, P.M., Pascucci, T.R., Gavras, J.N., Mardakhayava, E., Lund, E.K., 2019. Evolution of high tooth replacement rates in theropod dinosaurs. PloS one 14(11). e0224734. https://doi.org/10.1371/journal.pone.0224734 
Dutheil, D.B., 1999. The first articulated fossil cladistian, Serenoichthys kemkemensis, gen. et sp. nov., from the Cretaceous of Morocco. Journal of Vertebrate Paleontology 19, 243-246. https://doi.org/10.1080/02724634.1999.10011138

Edmund. A.G., 1962. Sequence and rate of tooth replacement in the Crocodilia. Royal Ontario Museum, Life Sciences Contribution 56, 1-42.

Erickson, G.M., 1996. Incremental lines of von Ebner in dinosaurs and the assessment of tooth replacement rates using growth line counts. Proceedings of the National Academy of Sciences, 93(25), 14623-14627.

Ettachfini, E.M., Andreu, B., 2004. Le Cénomanien et le Turonien de la plate-forme Préafricaine du Maroc. Cretaceous Research 25(2), 277-302.

Henderson, D.M., 2018. A buoyancy, balance and stability challenge to the hypothesis of a semiaquatic Spinosaurus Stromer, 1915 (Dinosauria: Theropoda). PeerJ 6, p.e5409.

Hendrickx, C., Mateus, O., Araújo, R., Choiniere, J., 2019. The distribution of dental features in nonavian theropod dinosaurs: Taxonomic potential, degree of homoplasy, and major evolutionary trends. Palaeontologia Electronica, 22(3).

Hone, D.W.E., Holtz, Jr, T.R., 2019. Comment on: Aquatic adaptation in the skull of carnivorous dinosaurs (Theropoda: Spinosauridae) and the evolution of aquatic habits in spinosaurids. 93, 275-284. Cretaceous Research 93, 275-284.

Ibrahim, N., Dal Sasso, C., Maganuco, S., Fabbri, M., Martill, D.M., Gorscak, E., Lamanna, M.C., 2016. Evidence of a derived titanosaurian (Dinosauria, Sauropoda) in the "Kem Kem beds" of Morocco, with comments on sauropod paleoecology in the Cretaceous of Africa. Cretaceous Period: Biotic Diversity and Biogeograph, 71, 149-159.

Ibrahim, N., Sereno, P.C., Dal Sasso, C., Maganuco, S., Fabbri, M., Martill, D.M., Zouhri, S., Myhrvold, N., lurino, D.A., 2014. Semiaquatic adaptations in a giant predatory dinosaur. Science 345(6204), 1613-1616.

Ibrahim, N., Maganuco, S., Dal Sasso, C., Fabbri, M., Auditore, M., Bindellini, G., Martill, D.M., Zouhri, S., Mattarelli, D.A., Unwin, D.M., Wiemann, J., Bonadonna, D., Amane, A., Jakubczak, J., Joger, U., Lauder, G.V., Pierce, S.E., 2020a. Tail-propelled aquatic locomotion in a theropod dinosaur. Nature 581, 67-70. https://doi.org/10.1038/s41586-020-2190-3 
401

402

403

404

405

406

407

408

409

410

411

412

413

414

415

416

417

418

419

420

421

Ibrahim, N., Sereno, P.C., Varricchio, D.J., Martill, D.M., Dutheil, D.B., Unwin, D.M., Baidder, L., Larsson, H.C., Zouhri, S., Kaoukaya, A., 2020b. Geology and paleontology of the Upper Cretaceous Kem Kem Group of eastern Morocco. ZooKeys, 928, 1-216.

Kellner, A.W., Azevedo, S.A., Machado, E.B., Carvalho, L.B.D., Henriques, D.D., 2011. A new dinosaur (Theropoda, Spinosauridae) from the Cretaceous (Cenomanian) Alcântara Formation, Cajual Island, Brazil. Anais da Academia Brasileira de Ciências 83(1), 99-108.

Kellner, A.W., Campos, D.D.A., 1996. First Early Cretaceous theropod dinosaur from Brazil with comments on Spinosauridae. Neues Jahrbuch für Geologie und Paläontologie, Abhandlungen 200, 151-166.

Kennedy, W.J., Gale, A.S., Ward, D.J., Underwood, C.J., 2008. Early Turonian ammonites from Goulmima, southern Morocco. Bulletin de l'Institut Royal des Sciences Naturelles de Belgique 78, 149-177.

Lakin, R.J., Longrich, N.R., 2019. Juvenile spinosaurs (Theropoda: Spinosauridae) from the middle Cretaceous of Morocco and implications for spinosaur ecology. Cretaceous Research 93, 129-142.

Lang, E., Boudad, L., Maio, L., Samankassou, E., Tabouelle, J., Tong, H., Cavin, L., 2013. Unbalanced food web in a Late Cretaceous dinosaur assemblage. Palaeogeography, Palaeoclimatology, Palaeoecology 381-382, 26e32. http://dx.doi.org/10.1016/j.palaeo.2013.04.011

Madsen, J.H., Jr. 1993. Allosaurus fragilis: A revised osteology. [Reprint.] Utah Geological Survey Bulletin, no. 109. 1-163.

Martill, D.M., Unwin, D.M., Ibrahim, N., Longrich, N., 2018. A new edentulous pterosaur from the Cretaceous Kem Kem beds of south eastern Morocco. Cretaceous Research 84, 1-12.

McCurry, M.R., Evans, A.R., Fitzgerald, E.M., McHenry, C.R., Bevitt, J., Pyenson, N.D., 2019. The repeated evolution of dental apicobasal ridges in aquatic-feeding mammals and reptiles. Biological Journal of the Linnean Society 127, 245-259.

McGowan, A.J., Dyke, G.J., 2009. A surfeit of theropods in the Moroccan Late Cretaceous? Comparing diversity estimates from field data and fossil shops. Geology 37(9), 843-846.

Milner, A.C., 2003. Fish-eating theropods: a short review of the systematics, biology and palaeobiology of spinosaurs. Journadas Internacionales sobre paleontologiá de Dinosaurios y su Entoro 2, 129-138. 
Richter, U., Mudroch, A., Buckley, L.G., 2013. Isolated theropod teeth from the Kem Kem beds (early Cenomanian) near Taouz, Morocco. Paläontologische Zeitschrift 87, 291-309.

Sereno, P.C., Dutheil, D.B., larochene, M., Larsson, H.C., Lyon, G.H., Magwene, P.M., Sidor, C.A., Varricchio, D.J., Wilson, J.A., 1996. Predatory dinosaurs from the Sahara and Late Cretaceous faunal differentiation. Science 272(5264), 986-991.

Slaughter, B.H., Springer, S., 1968. Replacement of rostral teeth in sawfishes and sawsharks. Copeia 3, 499-506.

Smith, J.B., Lamanna, M.C., Mayr, H., Lacovara, K.J., 2006. New information regarding the holotype of Spinosaurus aegyptiacus Stromer, 1915. Journal of Paleontology 80, 400-406.

Stovall, J.W., Langston, W., 1950. Acrocanthosaurus atokensis, a new genus and species of Lower Cretaceous Theropoda from Oklahoma. The American Midland Naturalist 43(3), 696-728.

Stromer, E., 1915. Ergebnisse der Forschungsreisen Prof. E. Stromers in den Wüsten Ägyptens. II. Wirbeltier-Reste der Baharije-Stufe (unterstes Cenoman). 3. Das Original des theropoden Spinosaurus aegyptiacus nov. gen., nov. spec. Abhandlungen der Königlich Bayerischen Akademie der Wissenschaften, Mathematisch-physikalische Klasse 28 (3), 1-32.

Stromer, E., 1931. Ergebnisse der Forschungsrisen Prof. E. Stromers in Short Communications 1055 den Wüsten Ägyptens. II. Wirbeltierreste der Baharje-Stufe (unterstes Cenoman). 10. Ein Skelett-Rest von Carcharodontosaurus no. gen. Abhandlungen der Bayerischen Akademie der Wissenschaften, Mathematisch-naturwissenschaftliche Abteilung, Neue Folge 9, 1-23.

Stromer, E., 1936. Ergebnisse der Forschungsreisen Prof. E. Stromers in den Wüsten Ägyptens. VII. Baharîje-Kessel und-Stufe mit deren Fauna und Flora. Eine ergänzende Zusammenfassung. Abhandlungen der Bayerischen Akademie der Wissenschaften, Mathematisch-naturwissenschaftliche Abteilung, Neue Folge 33, 1-102.

Sues, H.D., Frey, E., Martill, D.M., Scott, D.M., 2002. Irritator challengeri, a spinosaurid (Dinosauria: Theropoda) from the Lower Cretaceous of Brazil. Journal of Vertebrate Paleontology 22, 535547.

Taquet P., 1984. Une curieuse spécialisation du crâne de certains dinosaures carnivores du Crétacé: le museau long et étroit des spinosauridés. Comptes rendus de l'Académie des Sciences, Paris II 299, 217-222. 
460

461

462

463

464

465

466

467

468
Taquet, P., Russell, D.A., 1998. New data on spinosaurid dinosaurs from the Early Cretaceous of the Sahara. Comptes Rendus de l'Académie des Sciences-Series IIA-Earth and Planetary Science 327, 347-353.

Vullo, R., Allain, R., Cavin, L., 2016. Convergent evolution of jaws between spinosaurid dinosaurs and pike conger eels. Acta Palaeontologica Polonica 61, 825-828.

Zeffer, A., Johansson, L.C., Marmebro, Å., 2003. Functional correlation between habitat use and leg morphology in birds (Aves). Biological Journal of the Linnean Society 79, 461-484. 
Fig. 1. Map of the Tarda locality with extensive exposures of the Kem Kem Group. A, General map of the northern Tafilalt showing the major towns and location of the Tarda Oasis with field area indicated by the box. B, Detailed map with schematic geological overlay. Sites one and two are indicated by red and yellow stars respectively. The uncoloured area corresponds to the lower Ifezouane Formation, but in many places this is concealed by alluvial fans. The red star is located on an outcrop on the flanks of a small plateau formed by the Yellow Limestone Member.

Fig. 2. Preliminary stratigraphic log for the region between Sites 1 and 2 near Tarda. A, Log through the Ifezouane Formation including the Yellow Limestone Member. B, Simplified stratigraphic scheme for the region with range strata visible at Tarda indicated by black line.

Fig. 3. Photographs of exposures in the Tarda field area. A, View of the Ikfh n'Oufza escarpment taken from the small plateau shaded purple in Fig. 2 . Site 2 is just a few metres to the east of this view. B, View looking north with the unnamed plateau capped by the Yellow Limestone Member and $\mathrm{kffh}$ n'Oufza in the distance. C, Site 2 seen from Site 1 . The distance is just shy of $2 \mathrm{~km}$.

Fig. 4. Spinosaurus teeth at Site 1. A, Thin section in PPL through sandstone bone-bed with spinosaur teeth. The tooth broken tooth in this image is a Spinosaurus crown tip with maximum diameter of $2.5 \mathrm{~mm}$. B, as A but seen in XPL. C, a bag full of broken Spinosaurus teeth abandoned by the fossil diggers at Site 1 , presumably regarded as of no commercial value.

Fig. 5. Isolated vertebrate remains for Site 1 and Site 2 at Tarda, SE Morocco. Notice that the material is fragmentary, but not water worn. Hairline fractures in the material mean that specimens often fall apart when extracted, but some material was fragmented preburial, as seen in Fig. 4A, B. Scale bars $=10 \mathrm{~mm}$. A, rostral denticle of Onchoprisits cf. numidus; B, Lamnid shark indet.; C, fragment of vomerine dentition from pycnodont; D, unidentified large fish tooth; E, lungfish dental plate; F, tooth of abelisaurid indet.; $\mathrm{G}$, tooth of indeterminate theropod; $\mathrm{H}$, tooth of Spinosaurus sp.; I, tooth of Carcharodotosaurus sp.; J, tooth of titanosauroid sauropod indet.; K, tooth of indeterminate ornithocheirid pterosaur; L, tooth of pholidosaurid crocodile; M, Tooth of Elosuchus 

numidus; $\mathrm{P}$, fragment of indeterminate turtle carapace; $\mathrm{Q}$, teleost vertebra; $\mathrm{R}$, holostean scale; $\mathrm{S}$, indeterminate bone fragment.

503

Fig. 6. Pie charts displaying the relative abundance of vertebrate elements in assemblages from Sites 1 and 2 of the Tarda locality. A, All vertebrate elements from Site 1; B, teeth only from Site 1; C, all vertebrate elements from Site $2 ; D$, teeth only from Site 2 . See also Tables $1 A, B$, and $2 A, B$, for numerical abundances. See Fig. 5 for identifications.

508

509

Fig. 7. Spinosaurus sp. tooth morphotypes at Site 2, Tarda, Morocco. The three morphotypes recognised by Richter et al., (2013) are Mt.1a-c. In the pie chart slightly less than half the teeth could not be confidently placed in a morphotype. Scale bars $=10 \mathrm{~mm}$.

512

513

Table 1. Taxonomic abundances at Site 1. A, total taxonomic abundance; B, dental taxonomic abundance.

515

Table 2. Taxonomic abundances at Site 2. A, total taxonomic abundance; B, dental taxonomic 517 abundance.

Table 3. Tooth counts for a variety of theropod dinosaurs from the Kem Kem Group with data from related forms from other localities. Asterisks indicate incomplete specimens where tooth count could be higher. 

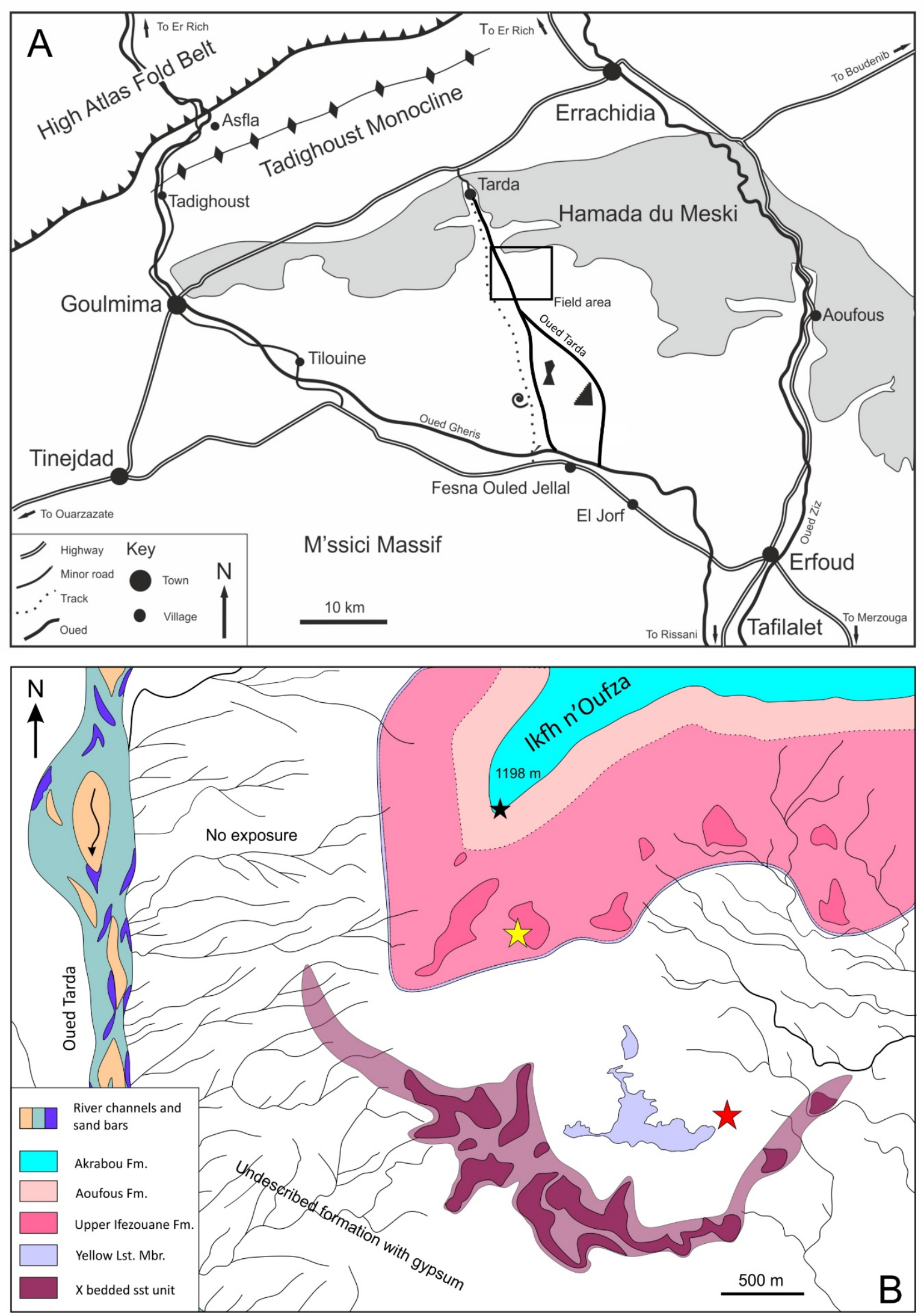


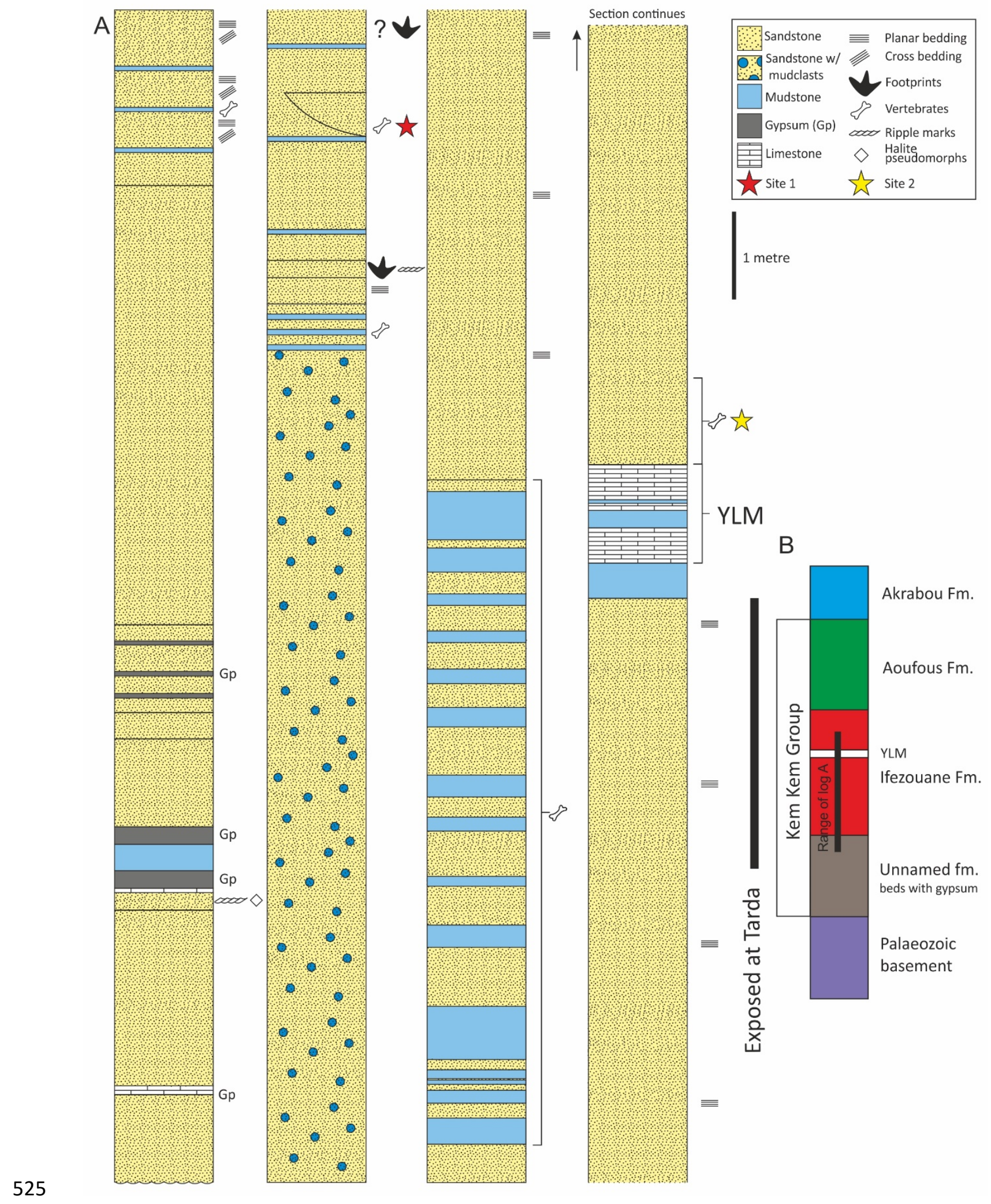


Akrabou Fm.
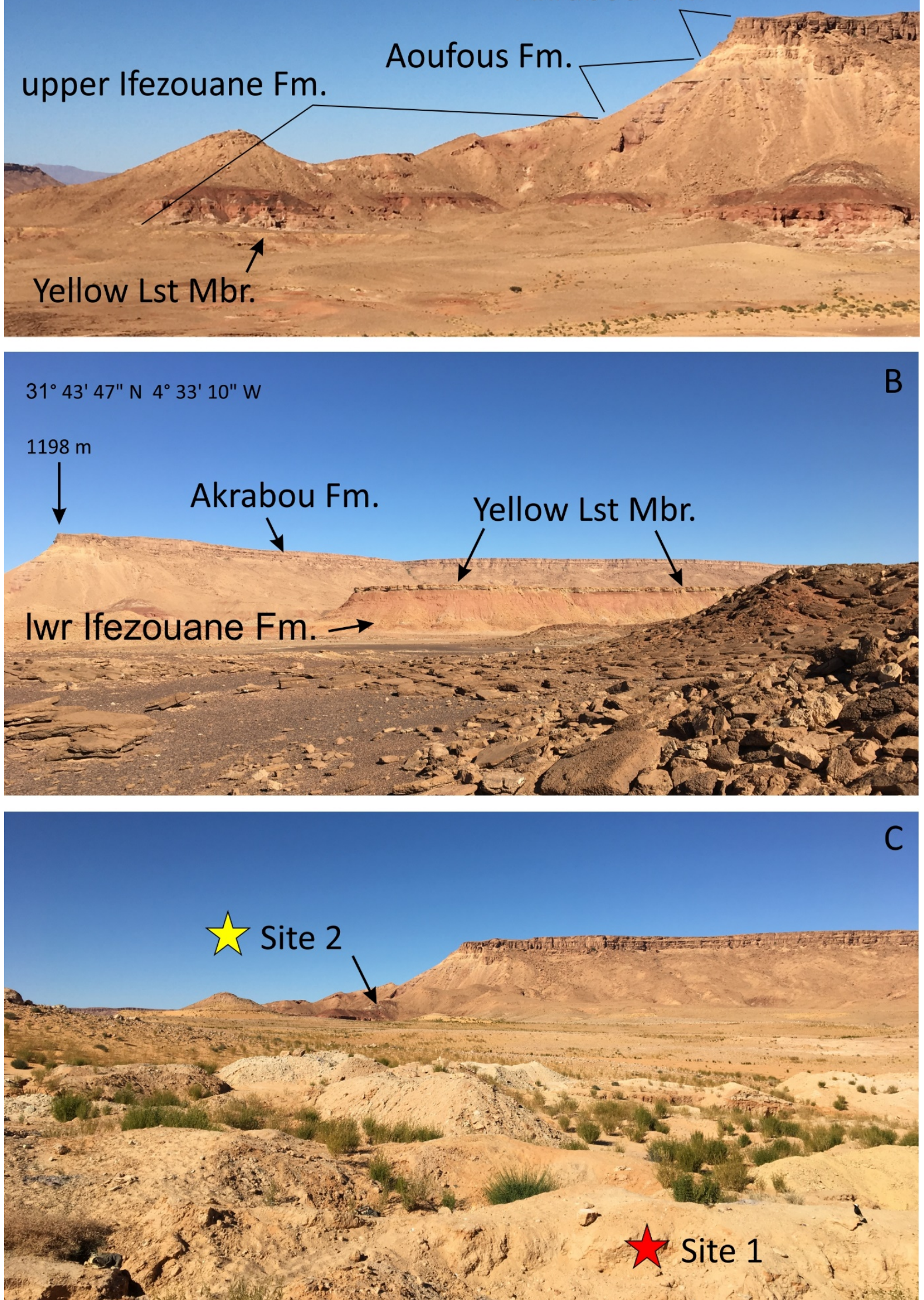

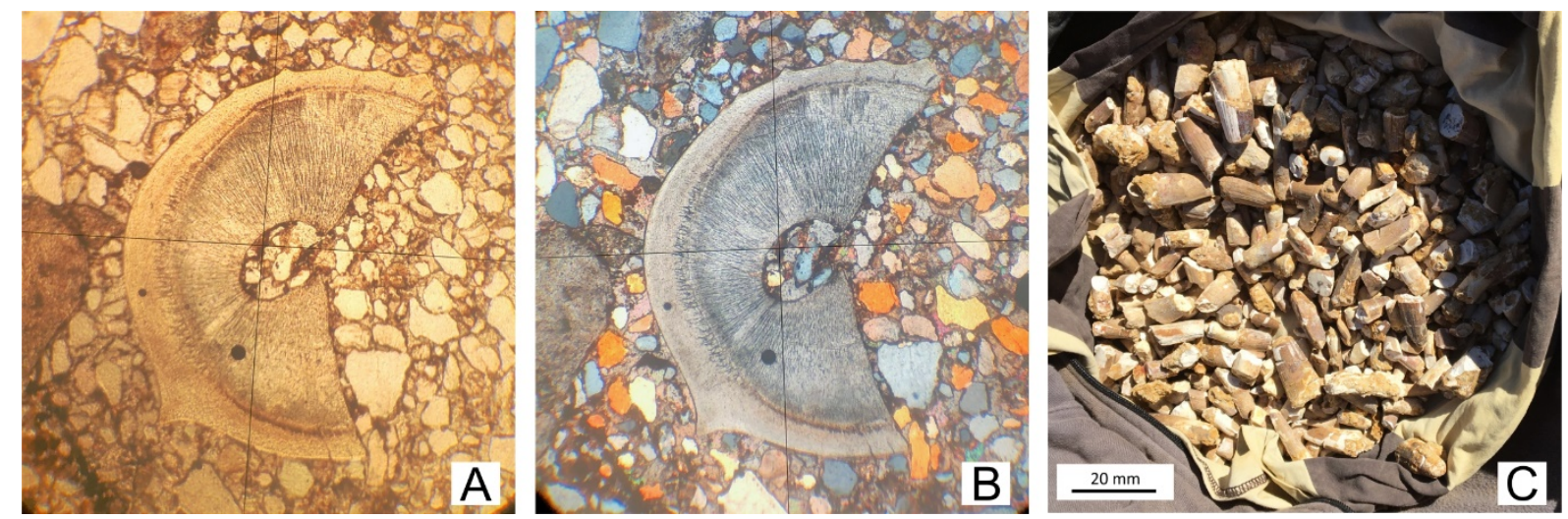

529 


\begin{tabular}{c|c|c|c|c}
\hline Morphotype & Abundance & \% & \% ex. indet. & \% Richter, et al., 2012 \\
\hline 1a & 120 & 29.5 & 53.3 & 60.0 \\
\hline 1b & 60 & 14.7 & 26.6 & 22.0 \\
\hline 1c & 45 & 11.1 & 20.0 & 18.0 \\
\hline Indet. & 182 & 44.7 & N/A & N/A \\
\hline Total & 407 & 100.0 & 99.9 & 100.0 \\
\hline
\end{tabular}

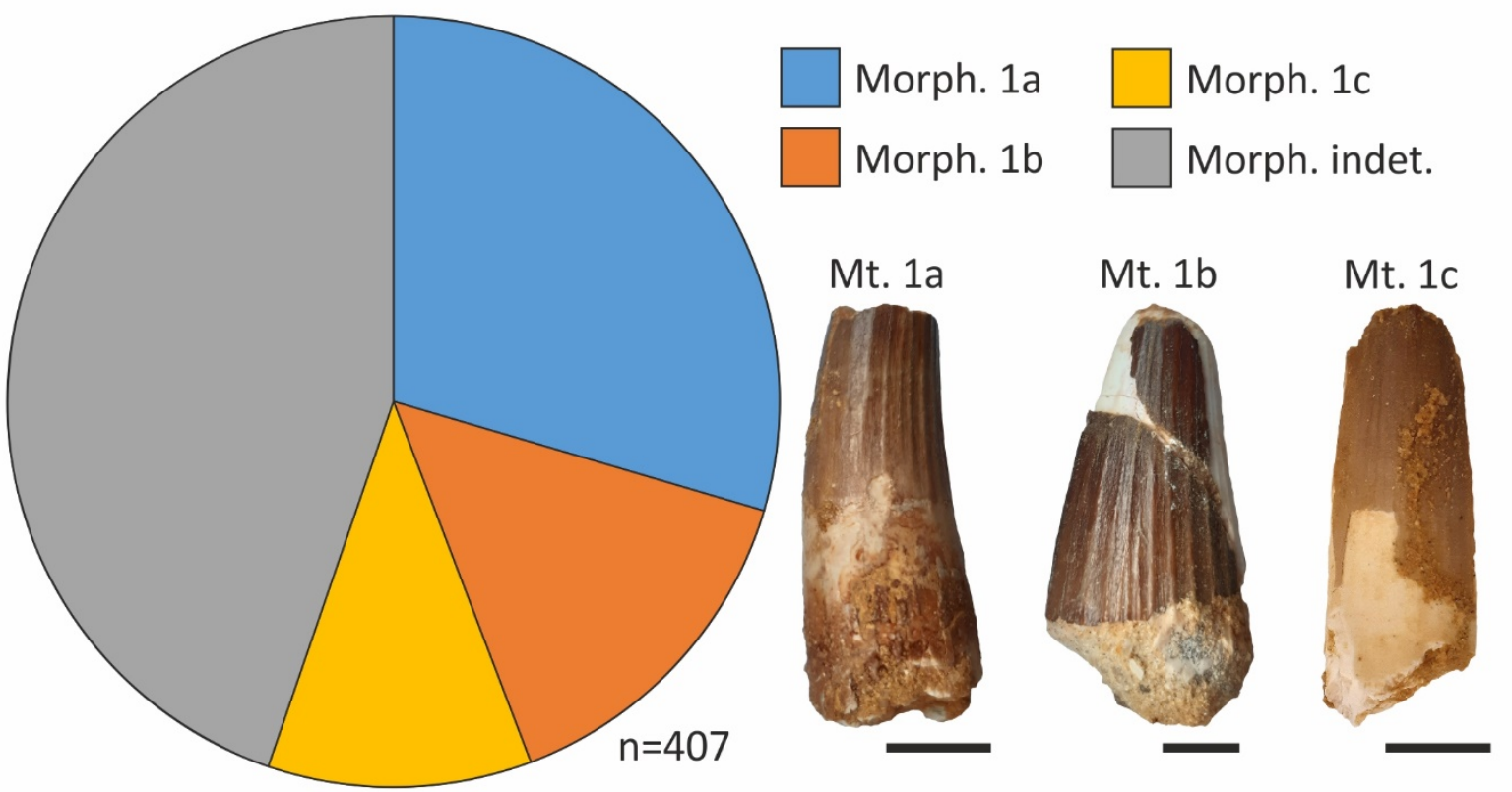



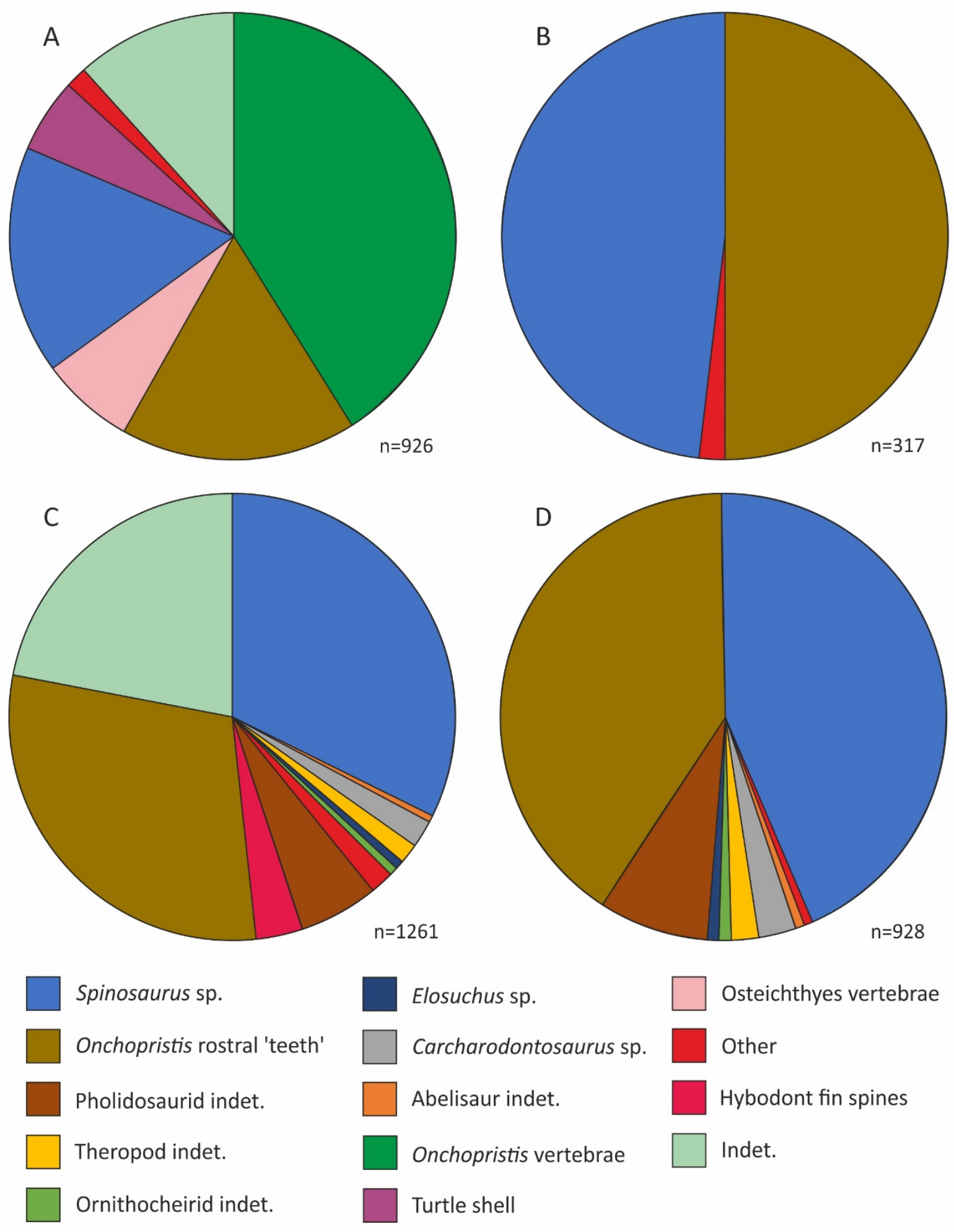


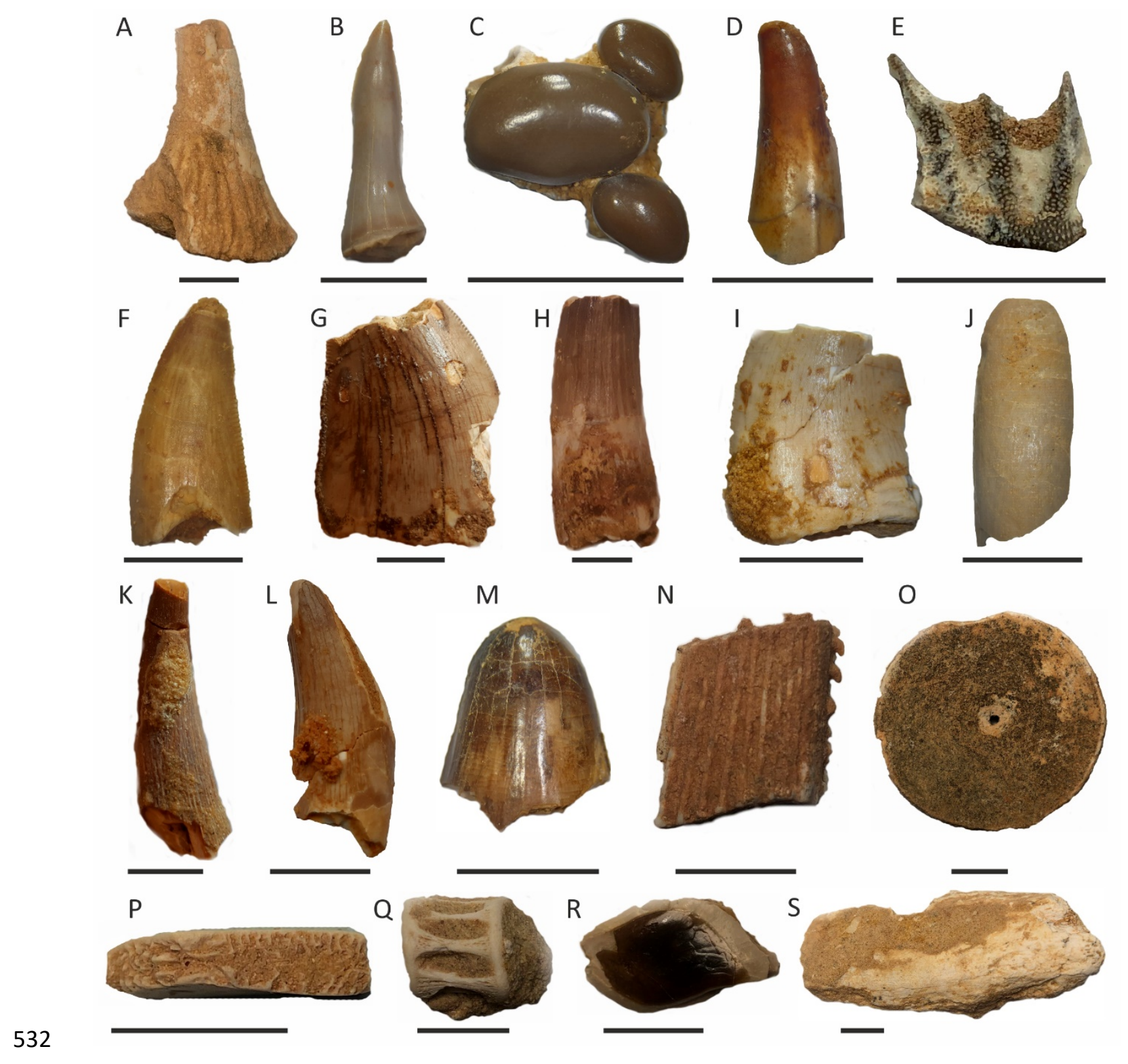


Table 1A. Tarda bone bed taxonomic abundance. Raw data $\mathrm{n}=926$.

Taxon

No. of Elements

Onchopristis numidus 381

vertebrae

Onchopristis numidus 159

rostral 'teeth'

Osteichthyes vertebrae 63

Lepidotes sp. teeth 3

Spinosaurus sp. teeth 152

Carcharodontosaurus 1

sp. teeth

Lungfish teeth $\quad 1$

Ganoid scales $\quad 2$

Hybodont shark fin 2

spine

Turtle shell

50

Crocodile tooth?

1

Pterosaur bones

3

Unidentifiable material 108

Total specimens

926
41.1

$\%$

17.2

6.8

0.3

16.4

0.1

0.1

0.2

0.2

$5 \cdot 4$

0.1

0.3

11.7

99.9
Palaeoecology

Aquatic

Aquatic

Aquatic

Aquatic

Semi-aquatic to aquatic

Terrestrial

Aquatic Freshwater

Aquatic

Aquatic

Aquatic

Semi-aquatic

Aerial

$\mathrm{N} / \mathrm{A}$ 
Table 1B. Tarda bone bed taxonomic abundance of teeth by taxon. Raw data $n=317$.

\section{Taxon}

Onchopristis numidus rostral 'teeth'

Lepidotes sp. $\quad 3$

Spinosaurus sp. $\quad 152$

Carcharodontosaurus 1

sp.

Lungfish

Crocodile?

Total specimens
No. of Elements

159

$3 \quad 0.9$

47.9

0.3

0.3

0.3

99.9
$\%$

Ecology

Aquatic

Aquatic

Semi-aquatic to aquatic

Terrestrial

Aquatic Freshwater

Semi-aquatic 
Table 2A. Taxonomic abundances at Site 2. A, total taxonomic abundance.

Taxon

Spinosaurus sp. teeth

Spinosaurus sp. neural spine

frag.

Abelisauroidea teeth

6

Carcharodontosaurus sp. teeth 25

Theropoda indet. teeth

19

Titanosauria teeth

3

Sauropoda indet. vert. frags

Ornithocheiridae teeth

Azhdarchidae jaw frag.

Elosuchus sp. teeth

Pholidosaurid indet. teeth

Crocodylomorpha indet. scutes

Serpentes trunk vertebrae

Hybodont shark fin spines

Lamniform shark tooth

Onchopristis numidus rostral

'teeth'

Onchopristis numidus rostral cartilage

Aidachar pankowskii tooth

Pycnodontiformes dentition

Holostean scales

Unidentified vertebrate

material

Total
No.

$\%$
32.3

0.1

0.5

2.0

1.5

0.2

0.2

0.6

0.1

0.6

5.8

0.2

0.2

$3 \cdot 3$

0.1

29.7

0.2

0.1

0.2

0.3

22.0

100 
Table 2B. Taxonomic abundances at Site 2. B, dental taxonomic abundance.

Taxon

Spinosaurus sp.

Abelisauroidea

Carcharodontosaurus sp.

Theropoda indet.

Titanosauria indet.

Ornithocheiridae indet.

Elosuchus sp.

Pholidosauridae indet.

Lamniform shark

Onchopristis numidus

Aidachar pankowskii

Pycnodontiformes

Totals
No. of teeth

407

6

25

19

3

8

8

73

1

375

1

2

928
$\%$

43.9

0.6

2.7

2.0

0.3

0.9

0.9

73

0.1

40.4

0.1

0.2

100 
Table 3. Tooth counts for a variety of theropod dinosaurs from the Kem Kem Group with data from related forms from other localities. Asterisks indicate incomplete specimens where tooth count could be higher.

\begin{tabular}{|c|c|c|c|c|c|}
\hline $\begin{array}{l}\text { Taxon \& } \\
\text { spec. no. }\end{array}$ & Dent. $(1+\mathbf{r})$ & $\underset{\text { r) }}{\operatorname{Premax}}(1+$ & $\operatorname{Max} .(1+\mathbf{r})$ & Total count & Source \\
\hline $\begin{array}{l}\text { Spinosaurus } \\
\text { aegyptiacus } \\
\text { Holotype BSP } \\
1912 \text { VIII } 19\end{array}$ & 32 & ? & ? & & $\begin{array}{l}\text { Stromer 1915; } \\
\text { Smith et al., } \\
2006\end{array}$ \\
\hline $\begin{array}{l}\text { Spinosaurus } \\
\text { cf. } \\
\text { aegyptiacus } \\
\text { MSNM V4047 }\end{array}$ & ? & 12 & 24 & & $\begin{array}{l}\text { Dal Sasso et al. } \\
(2005)\end{array}$ \\
\hline $\begin{array}{l}\text { Spinosaurus } \\
\text { sp. } \\
\text { NHMUK } \\
16665\end{array}$ & ? & 14 & $*_{16+}$ & & Milner (2003) \\
\hline $\begin{array}{l}\text { Spinosauridae } \\
\text { indet. } \\
\text { FSAC-KK-7281 }\end{array}$ & ? & $* 10+$ & ? & & $\begin{array}{l}\text { Lakin and } \\
\text { Longrich } \\
\text { (2019) }\end{array}$ \\
\hline $\begin{array}{l}\text { Spinosaurus } \\
\text { moroccanus } \\
\text { MNHN SAM } \\
124\end{array}$ & ? & 14 & $* 18+$ & & $\begin{array}{l}\text { Taquet and } \\
\text { Russell (1998) }\end{array}$ \\
\hline $\begin{array}{l}\text { cf. } \\
\text { Spinosaurus } \\
\text { aegyptiacus } \\
\text { NHMUK PV R } \\
16421\end{array}$ & $* 34+$ & ? & ? & & Milner (2003) \\
\hline $\begin{array}{l}\text { Compiled } \\
\text { average for } \\
\text { Spinosaurus }\end{array}$ & 32 & 14 & 24 & 70 & \\
\hline $\begin{array}{l}\text { "Oxalaia } \\
\text { quilombensis" } \\
\text { UFRJ MN } \\
\text { 6117-V }\end{array}$ & ? & 14 & ? & $14^{+}$ & $\begin{array}{l}\text { Kellner et al. } \\
\text { (2011) }\end{array}$ \\
\hline $\begin{array}{l}\text { Irritator } \\
\text { challengeri } \\
\text { SMNS } 58022\end{array}$ & ? & ? & $* 20+$ & $20+$ & $\begin{array}{l}\text { Sues et al. } \\
(2002)\end{array}$ \\
\hline $\begin{array}{l}\text { Angaturama } \\
\text { limai } \\
\text { USP GP/2T-5 }\end{array}$ & ? & 14 & $* 6+$ & $20+$ & $\begin{array}{l}\text { Kellner and } \\
\text { Campos (1996) }\end{array}$ \\
\hline $\begin{array}{l}\text { Baryonyx } \\
\text { walkeri }\end{array}$ & 64 & $12 / 14$ & $* 16+$ & $94^{+}$ & $\begin{array}{l}\text { Charig and } \\
\text { Milner, } 1997\end{array}$ \\
\hline
\end{tabular}


NHMUK PV R

9951

Carcharodont ?

osaurus

saharicus

Holotype

Carcharodont ?

osaurus

saharicus

Neotype

SGM-Din 1

Carcharodont ?

osaurus

iguidensis

UCRC PV12

Carcharodont $* 8+$

osaurus

saharicus

NMC 41859

Neovenator *26+

salerii

MIWG 6348

Acrocanthosa 34

urus atokensis

Holotype

M.U.O. 8-0-S9

Allosaurus 28-34 (Av. 32) 10

fragilis

Allosaurus $\quad 40$

jimmadseni

DINO 11541

Giganotosaur 30

us carolinii

Holotype

MUCPv-Ch1

Estimated 30

tooth count for

Carcharodont

osaurus

8

24
?

*20+

Recon. at 24

Sereno et al.

(1996)

Brusatte and Sereno, 2007; see also Ibrahim et al., 2020b

Ibrahim et al., 2020a, Ibrahim et al., 2020b

$66+$

Brusatte et al. (2008)

Stovall and

Langston

(1950)

28-34

Madsen (1993)

32

80

Chure and

Loewen

(2020)

8

*24+

$62+$

Coria and Salgado (1995)

62 